DIMENSI, VOL. 8 , NO. 3 : 404-418

NOVEMBER 2019

ISSN: 2085-9996

\title{
PENGARUH BOOK TAX GAP DAN KEPEMILIKAN ASING TERHADAP PENGHINDARAN PAJAK DAN ANALISIS KEBIJAKAN PEMERINTAH TERKAIT PENGHINDARAN PAJAK
}

\section{THE EFFECT OF BOOK TAX GAP AND FOREIGN OWNERSHIP ON COMPANY TAX AVOIDANCE AND ANALYSIS OF GOVERNMENT REGULATIONS RELATED TO TAX AVOIDANCE}

\author{
Muhammad Hidayat ${ }^{1}$, Rahmayandi Mulda ${ }^{2}$ \\ I(Prodi Akuntansi, Fakultas Ekonomi, UNRIKA, Indonesia) \\ ${ }^{2}$ (Prodi Ilmu Pemerintahan, FISIPOL, UNRIKA, Indonesia) \\ Imhidayatb@fekon.unrika.ac.id,r2rahmayandim@yahoo.co.id
}

\begin{abstract}
Abstrak
Penelitian ini bertujuan untuk menguji apakah books tax gap dan kepemilikan asing berpengaruh signifikan terhadap penghindran pajak, serta menganalisis kebijakan yang sudah dilakukan pemerintah terkait penghindaran pajak. Penelitian dilakukan pada sektor industri makanan dan minuman yang terdaftar di BEI tahun 2017-2018. Penelitian menggunakan alisis regresi linier berganda untuk menguji apakah ada pengaruh book tax gap dan kepemilikan asing terhadap penghindaran pajak. Penelusuran data pustaka dilakukan untuk menganalisis kebijakan pemerintah terkait penghindaran pajak.

Hasil dari penelitian ini menunjukkan bahwa secara parsial book tax gap berpengaruh signifikan terhadap penghindaran pajak namun kepemilikan asing tidak berpengaruh signifikan terhadap penghindaran pajak. Pemerintah sudah melakukan upaya menangkal penghindaran pajak ini dengan regulasi meskipun masih perlu untuk terus disempurnakan.
\end{abstract}

Kata Kunci ; Books Tax Gaps, Kepemilikan Asing, Penghindaran Pajak

\begin{abstract}
This study aims to examine whether book tax gap and foreign ownership have a significant effect on tax avoidance, and to analyze policies that have been carried out by the government regarding tax avoidance. The study was conducted in the food and beverage industry sector listed on the IDX in 2017-2018. The study uses multiple linear regression analysis to test whether there is an effect of book tax gap and foreign ownership of tax avoidance. Library data search is done to analyze government policies related to tax avoidance.

The results of this study indicate that partially the book tax gap has a significant effect on tax avoidance but foreign ownership has no significant effect on tax avoidance. The government has made efforts to ward off this tax avoidance with regulations even though it still needs to be improvement.
\end{abstract}

Keywords; Book Tax Gaps, Foreign Ownership, Tax Avoidance 


\section{PENDAHULUAN}

\section{Latar Belakang Masalah}

Sebagai sumber penerimaan utama suatu Negara pajak merupakan hal yang sangat penting sehingga sering menjadi isu nasional maupun internasional. Sebagai sebuah negara besar Indonesia belum mampu mengumpulkan pajak yang memadai jika dibandingkan dengan negara berkembang lain. Dari data kementerian keuangan Republik Indonesia diketahui bahwa rasio pajak di Indonesia pada tahun 2017 adalah 10.7\% (http:// www.pajak.go.id/faq/31230/86-rasio-pajak-tax-ratio-dari-masa-ke-masa, Maret 2019), ini masih jauh lebih rendah dibandingkan negara tetangga seperti Malaysia dan Singapura yang rasio pajaknya sudah mencapai 14\% - 15\% sedangkan rasio pajak di Negara-negara Eropa rata-rata sudah melebihi 20\%. Adapun yang dimaksud dengan Rasio pajak adalah perbandingan antara penerimaan pajak suatu negara dengan produk domestik bruto (PDB). Bank Dunia menyatakan bahwa rasio pajak suatu negara dapat $\begin{array}{llll}\text { dikatakan } & \text { baik } & \text { jika } & \text { mencapai }\end{array}$ (https://ekonomi.kompas.com/read/2018/10/04/193900426/imf, Maret 2019).

Memang tidak dapat dipungkiri bahwa dalam implementasinya terdapat perbedaan kepentingan antara perusahaan (wajib pajak) dan pemerintah. Bagi perusahaan pajak merupakan biaya atau beban yang akan mengurangi laba bersih perusahaan. Jika perusahaan memperoleh keuntungan yang besar maka pajak penghasilan yang dibayarkan ke negara juga besar. Oleh sebab itu perusahaan sangat mungkin jika berupaya untuk membayar pajak sekecil mungkin. Di lain pihak, pemerintah memerlukan dana yang setiap tahunnya semakin besar untuk membiayai pembangunan dan penyelenggaraan pemerintahan.

Beberapa tahun belakangan ini telah terjadi keluhan dibeberapa negara dimana ada perusahaan-perusahaan besar membayar pajak sangat kecil sementara omsetnya sangat besar. Ivestigasi yang diungkapakan oleh Kantor Berita Reuters misalnya tentang Starback di Inggris yang membayar pajak sangat kecil bahkan sering dengan laporan keuangan rugi, logikanya bagaimana bisa bertahan selama 14 tahun jika tidak menguntungkan. Sebanyak 2.000 perusahaan multinasional yang beroperasi di Indonesia tidak membayar Pajak Penghasilan (PPh) Badan Pasal 25 dan Pasal 29 karena alasan 
merugi (Liputan6.com 2016 https://www.liputan6. com/bisnis/ read/2469089/ 2000perusahaan- asing- gelapkan -pajak-selama 10-tahun, Februari 2019).

Adapun upaya penghindaran pajak ini merupakan masalah tersendiri dan sulit dibuktikan, karena biasanya ini dilakukan dengan memanfaatkan celah yang ada pada aturan perpajakan. Menurut Suryana (2013) praktik penghindaran pajak (Tax avoidance) dapat dilakukan dengan berbagai modus seperti:

a) Modus franchisor yaitu dengan membuat laporan keuangan seolah rugi;

b) Modus pembelian bahan baku dari perusahaan satu grup. Pembelian bahan baku dilakukan dengan harga mahal dari perusahaan satu grup yang berdiri di negara bertarif pajak rendah;

c) Modus berhutang atau menjual obligasi kepada afiliasi perusahaan induk dan membayar kembali cicilan dengan bunga sangat tinggi;

d) Modus menggeser biaya usaha ke negara bertarif pajak tinggi (cost center) dan mengalihkan profit ke negara bertarif pajak rendah (profit center). Dengan demikian keuntungan perusahaan terlihat kecil dan tidak perlu membayar pajak korporasi;

e) Modus menarik deviden lebih besar dengan menyamarkan biaya royalti dan jasa manajemen untuk menghindari pajak korporasi;

f) Modus terakhir adalah dengan mengecilkan omset penjualan.

Manfaat dari adanya penghindaran pajak adalah untuk memperbesar tax saving yang berpotensi mengurangi pembayaran pajak sehingga akan menaikkan cash flow (Guire et al, 2011). Menurut Rego (2003) dalam Dewi dan Jati (2014) semakin besar ukuran perusahaannya, maka transaksi yang dilakukan akan semakin kompleks. Jadi hal itu memungkinkan perusahaan untuk memanfaatkan celah-celah yang ada untuk melakukan tindakan tax avoidance dari setiap transaksi. Selain itu perusahaan yang beroperasi lintas negara memiliki kecenderungan untuk melakukan tindakan tax avoidance yang lebih tinggi dibandingkan perusahaan yang beroperasi lintas domestik. Kurniasih dan Ratnasari (2013) yang menemukan bahwa ukuran perusahaan berpengaruh signifikan terhadap penghindaran pajak. 
Salah satu isu yang berkembang mengenai analisis peraturan perpajakan yang menarik banyak perhatian adalah book-tax differences yaitu perbedaan antara pendapatan kena pajak menurut peraturan perpajakan dan pendapatan sebelum kena pajak menurut standar akuntansi. Peraturan perpajakan dan akuntansi memiliki tujuan yang berbeda sehingga perbedaan tersebut muncul hampir di semua negara (Martani dan Persada, 2010). Terjadinya fenomena book-tax differences ini menimbulkan peluang terjadinya manajemen laba dan kualitas laba perusahaan. Perbedaan antara laba akuntansi dan laba fiskal (book tax differences) dapat memberikan informasi mengenai kualitas laba (Comprix et al. 2011).

Jika tujuan dari tax planning ini adalah merencanakan agar beban pajak dapat ditekan serendah mungkin dengan memanfaatkan peraturan yang ada tetapi berbeda dengan tujuan pembuat undang-undang, maka perencanaan pajak dari sisi pemerintah adalah bagaimana untuk memaksimalkan pendapatan Negara melalui pajak (Fadilah : 2014). Perkembangan yang sangat cepat didunia usaha di era digital sekarang ini tidak dapat disangkal bahwa pemerintahan diberbagai Negara cukup kewalahan karena sering terlambat dalam membuat regulasi. Di Indonesia sendiri sebenarnya reformasi perpajakan dimulai sejak ditetapkannya beberapa undang undang terkait perpajakan Nomor 6 tahun 1983 tentang Ketentuan Umum dan Tata Cara Perpajakan, UU Nomor 7 tahun 1983 tentang Pajak Penghasilan (PPh). Dan kemudian ditetapkannya system pemingutan pajak dengan system self assessment. Yang terakhir adalah kebijakan pemerintah terkait ebiling yang mulai berlaku sejak tahun 2016 dengan maksud untuk mempermudah wajib pajak dalam melakukan pelaporan pajak.

\section{Rumusan Masalah}

Berdasarkan latar belakang masalah diatas maka dapat disimpulkan rumusan masalah dalam penelitian ini adalah:

1. Apakah kepemilikan asing berpengaruh signifikan terhadap Tax Avoidance?

2. Apakah book tax Gap, berpengaruh signifikan terhadap Tax Avoidance?

3. Apakah kepemilikan asing dan book tax Gap berpengaruh signifikan terhadap Tax Avoidance? 
4. Bagaimana kebijakan pemerintah untuk mengantisipasi Tax Avoidance di Indonesia?

\section{Tujuan dan Manfaat Penelitian}

Adapun tujuan penelitian ini adalah untuk membuktikan apakah variable-variabel dimaksud sepertai ukuran perusahaan, kepemilikan asing dan tax book difference berpengaruh terhadap upaya penghindaran pajak pada perusahaan manufaktur yang terdapat di Bursa Efek Indonesia. Disamping itu peneliti akan menguraikan bagaimana kebijakan-kebijakan pemerintah dibidang perpajakan untuk mengantisipasi upaya penghindaran pajak perusahaan.

Adapun out come yang diharapkan dari penelitian ini adalah dapat berupa jurnal yang akan dipublikasikan pada jurnal nasional terakreditasi, dan akan menghasilkan tambahan media pembelajaran berupa hand-out pada matakuliah Akuntansi Perpajakan.

\section{TINJAUAN PUSTAKA}

\section{Penghindaran Pajak}

Penghindaran pajak (Tax Avoidance) merupakan upaya Wajib Pajak dalam memanfaatkan peluang - peluang yang ada dalam undang - undang perpajakan sehingga Wajib Pajak dapat membayar pajaknya menjadi lebih rendah. Lim (2010) mendefinisikan penghindaran pajak sebagai penghematan pajak yang timbul dengan memanfaatkan ketentuan perpajakan yang dilakukan secara legal untuk meminimalkan kewajiban Hanlon \& Heitzman (2010) dalam Carolina et al. (2014) menyatakan bahwa tax avoidance merupakan rangkaian aktivitas perencanaan pajak dengan tujuan mengurangi jumlah pajak secara eksplisit. Menurut Martatilova (2012) Dibanyak Negara penghindaran pajak ini dikategorikan menjadi acceptable tax avoidance dan unacceptable tax avidance, dimana penghindaran pajak yang dilakukan secara agresif termasuk yang merupakan penghindaran pajak yang tidak diperkenankan.

Contoh penghindaran pajak adalah dengan cara mengarahkan transaksi pada transaksi yang bukan merupakan objek pajak ataupun mengarahkan transaksi yang menghasilkan biaya yang diperkenankan oleh undang-undang sebagai penghasilan kena 
pajak (Carolina et al, 2014). Adapun cara perusahaan melakukan penghindaran pajak menurut Merks (2007) dalam Kurniasih \& Sari (2013) adalah sebagai berikut:

a. Memindahkan subjek pajak dan atau objek pajak ke Negara-negara yang memberikan perlakuan pajak khusus atau keringanan pajak (tax haven country) atas suatu jenis penghasilan (substantive tax planning)

b. Usaha penghindaran pajak dengan mempertahankan substansi ekonomi dari transaksi melalui pemilihan formal yang memberikan beban pajak yang paling rendah (formal tax planning)

c. Ketentuan anti avoidance atas transaksi transfer pricing, thin capitalization, treaty shopping dan controlled foreign corporation (Specific Anti Avoidance Rule), serta transaksi yang tidak mempunyai substansi bisnis (General Anti Avoidance Rule).

Menurut Dyreng et al., (2010) Tax Avoidance dapat dihitung melalui Cash ETR (cash effective tax rate) perusahaan yaitu kas yang dikeluarkan untuk biaya pajak dibagi dengan laba sebelum pajak. Adapun rumus untuk menghitung Cash ETR adalah sebagai berikut:

$$
\text { Cash ETR }=\frac{\text { Pembayaran Pajak }}{\text { Laba Sebelum Pajak }}
$$

Semakin besar Cash ETR ini mengindikasikan semakin rendah tingkat penghindaran pajak perusahaan.

\section{Kepemilikan asing}

Dalam Pasal 1 ayat 8 UU Nomor 25 Tahun 2007 menyebutkan bahwa Modal Asing adalah Modal yang dimiliki oleh negara asing, perseorangan warga negara asing, dan Badan Hukum Indonesia yang sebagian atau seluruh modalnya dimiliki oleh pihak asing. Mengacu pada pasal diatas maka dapat disimpulkan bahwa kepemilikan saham asing merupakan proporsi saham biasa perusahaan yang dimiliki oleh perorangan, badan hukum, pemerintah serta bagian-bagiannya yang berstatus luar negeri (Anggraini, 2011). Entitas asing yang memiliki saham sebesar 20\% atau lebih sehingga dianggap memiliki pengaruh signifikan dalam mengendalikan perusahaan bisa disebut sebagai pemegang saham pengendali asing. Pemegang saham pengendali asing ini akan memungkinkan untuk memerintahkan manajemen untuk melakukan apa yang ia inginkan yang dapat 
menguntungkan dirinya (Putri,2016) Penalaran tersebut didukung penelitian sebelumnya oleh Ibrahim Aramide Salihu, Hairul Azlan dan Siti Normala (2015) bahwa semakin tinggi tingkat kepemilikan saham oleh pihak asing pada sebuah perusahaan maka semakin tinggi juga perusahaan tersebut untuk melakukan penghindaran pajak.

\section{Book Tax Gap}

Book Tax Gap atau sering juga disebut dengan Book Tax difference adalah perbedaan buku antara laporan keuangan bisnis dan laporan keuangan untuk perpajakan yang diakibatkan oleh adanya perbedaan standar akuntansi dan ketentuan perpajakan. Dasar yang berbeda dalam penyusunan laporan keuangan tersebut dapat menimbulkan terjadinya perbedaan perhitungan laba rugi perusahaan. Perbedaan itulah yang menimbulkan istilah book-tax differences dalam analisis perpajakan (Resmi, 2011:369). Book-tax gap dapat terjadi akibat perbedaan yang bersifat permanen dan bersifat sementara (Resmi, 2014:373). Perbedaan yang bersifat permanen disebabkan karena tidak semua pendapatan ataupun biaya yang diakui menurut akuntansi juga diakui menurut fiskal. Sedangkan, perbedaan sementara terjadi akibat dari perbedaan waktu pengakuan pendapatan ataupun biaya dalam menghitung jumlah laba. Book-tax gap yang bersifat sementara (temporary book-tax differences) dapat mengungkapkan tentang keleluasaan akrual akuntansi.

Adapun dalam penelitian ini peneliti mengukur book tax gap dengan mengunakan perbedaan temporer (temporay gap) yang dihitung dengan membagi total perbedaan temporer dengan total asset :

\section{Book Tax Gap: $\frac{\text { (Laba Akuntansi - Laba Pajak) }}{\text { Total Aktiva }}$}

\section{Kebijakan Pemerintah terkait Penghindaran Pajak}

Menurut Uppal dan Reksohadiprodjo 1999 dalam Makhfatih 2005 menyebutkan bahwa salah satu motif dari praktik penghindaran pajak di Indonesia disebabkan rendahnya pengawasan dan kurangnya regulasi. Tidak hanya di Indonesia bahkan di Negara-negara majupun selalu akan mengalami bahwa regulasi ketinggalan dengan perkembangan teknologi dan industry. Dengan demikian suatu keniscayaan bahwa regulasi-regulasi baru harus dibuat sesuai dengan kebutuhan perkembangan yang ada. 
Dalam penelitian ini akan dibahas perkembangan regulasi yang ada Indonesia yang dimaksudkan untuk menangkal praktik penghindaran pajak. Dalam penelitian ini akan penulis akan mendeskripsikan kebijakan-kebijakan yang sudah dibuat oleh pemerintah untuk menangkal upaya praktek penghindaran pajak. Dalam Ning Rahayu 2010 diketahui ada beberapa skema atau modus dalam melakukan penghindaran pajak perusahaan yaitu:

1. Transfer Pricing, ini adalah modus penghindaran pajak yang bisa dilakukan oleh perusahaan multi nasional dengan cara melakukan transaksi barang ataupun jasa dengan perusahaan yang terafiliasi diluar negeri dengan harga yang tidak wajar sehingga perusahaan yang ada didalam negeri labanya berkurang atau bahkan rugi.

2. Thin Capitalization, situasi di mana perusahaan melakukan pendanaan melalui tingkat utang yang tinggi dibandingkan modal yang dimiliki, dengan demikian laba perusahaan akan terkuras oleh beban bunga yang tinggi. Beban bunga ini terkadang mengalir ke perusahaan induk diluar negeri.

3. Treaty Shopping, ini dikategorikan sebagai sebuah upaya penyalahgunaan P3B (tax treaty). Yaitu suatu skema yang dirancang untuk mendapatkan fasilitas perpajakan. Seperti fasilitas penurunan tarif pemotongan pajak (withholding taxes) yang diberikan akibat suatu Perjanjian Pajak Berganda (P3B), oleh subjek pajak yang sesungguhnya tidak berhak mendapatkan fasilitas tersebut.

4. Controlled Foreign Corporation (CFC)

Modus yang umum dalam skema CTC adalah dengan memanfaatkan adanya hubungan istimewa dan kepemilikan mayoritas sahamnya, badan usaha di luar negeri yang dapat dikendalikan sehingga dividen tersebut tidak dibagikan atau ditangguhkan (Arnold and McIntyre 2002, 81).

\section{METODOLOGI (Material dan Metode)}

\section{Jenis dan Sumber Data}

Data dalam penelitian ini adalah data skunder berupa laporan keuangan perusahaan Manufaktur yang terdaftar di Bursa Efek Indonesia (BEI) tahun 2016-2017. 
Selain itu juga menggunakan data berupa peraturan perundang-undangan perpajakan terkait yang berlaku saat ini di Indonesia.

\section{Populasi dan Sampel}

Populasi dalam penelitian ini adalah seluruh perusahaan manufaktur yang terdaftar di Bursa Efek Indonesia (BEI) periode 2016 - 2017. Sedangkan sampel di tentukan berdasarkan kriteria sebagai berikut :

1. Perusahaan manufaktur yang terdaftar di BEI periode tahun 2016-2017.

2. Perusahaan yang memiliki laporan keuangan lengkap yang telah diaudit Akuntan Publik.

3. Perusahaan yang memiliki data lengkap sesuai dengan kebutuhan penelitian dan menggunakan mata uang Rupiah dalam pelaporannya.

\section{Teknik Analisis Data}

\section{Uji Asumsi Klasik}

a. Uji Normalitas

Menurut Ghozali (2016:154), uji normalitas dilakukan untuk menguji apakah dalam model regresi variabel residual memiliki distribusi normal. Model regresi yang baik adalah memiliki distribusi data normal atau mendekati normal. Untuk mendeteksi normalitas dapat dilakukan dengan uji statistik. Test statistic yang digunakan antara lain analisis normal probability plots dan Kolmogorov-Smirnov test.

b. Multikolinearitas

Pengujian asumsi kedua adalah uji multikolinearis (multicollinearity) antar variabel-variabel independen yang masuk ke dalam model. Metode untuk mendiagnosa adanya multicollinearity dilakukan dengan uji Varience Inflation Factor (VIF). Jika VIF lebih besar dari 10, maka antar variabel bebas terjadi persoalan multikolinearitas. Menurut Ghozali (2016:103), uji multikolinearitas bertujuan untuk menguji apakah model regresi ditemukan adanya korelasi antar variabel bebas.

c. Uji Heteroskedastisitas

Menurut Ghozali (2016:134),uji heteroskedastisitas bertujuan untuk menguji apakah dalam model regresi terjadi ketidaksamaan varian dari residual satu pengamat ke pengamat lain. Dalam penelitian ini akan dilakukan dengan uji Glesjer, jika variabel 
bebas memiliki tingkat signifikan diatas 0.05 atas residual mutlak persamaan maka dapat disimpulkan bahwa varians data adalah homoskedastisitas.

d. Uji Autokorelasi

Uji autokorelasi bertujuan untuk menguji apakah dalam suatu model regresi linier ada korelasi antara kesalahan pengganggu pada periode t-1 (sebelumnya). Jika terjadi korelasi maka dinamakan ada problem autokerelasi. Untuk menguji keberadaan autocorrelation dalam penelitian ini digunakan metode Durbin-Watson test.

\section{Uji Hipotesis}

a. Uji t

Uji t digunakan untuk menguji secara parsial masing-masing variabel. Hasil uji t dapat dilihat pada tabel coefficients pada kolom sig (significance). Dengan probabilitas nilai t atau signifikansi $<0,05$, maka dapat dikatakan bahwa terdapat pengaruh antara variabel bebas terhadap variabel terikat secara parsial. Namun, jika probabilitas nilai t atau signifikansi $>0,05$, maka dapat dikatakan bahwa tidak terdapat pengaruh yang signifikan antara masing-masing variabel bebas terhadap variabel terikat.

b. Uji F

Uji F dilakukan untuk mengetahui pengaruh kepemilikan asing dan book tax income difference (variabel bebas) secara bersama-sama terhadap tax avoidance (variabel terikat) dengan tingkat signifikansinya 0,05 . Jika nilai probabilitas $<0,05$, maka dapat dikatakan terdapat pengaruh yang signifikan secara bersama-sama antara variabel bebas terhadap variabel terikat. Namun, jika nilai signifikansi $>0,05$ maka tidak terdapat pengaruh yang signifikan secara bersama-sama antara variabel bebas terhadap variabel terikat.

\section{c. Literatur Review}

Literatur review ini dilakukan dengan menganalisis informasi dengan mempelajari dan menafsirkan peraturan dan undang-undan perpajakan, sehingga dapat disimpulkan bagaimana kebijakan yang telah dibuat pemerintah terkait upaya mengantisipasi penghindaran pajak badan usaha di Indonesia. 


\section{PEMBAHASAN}

\section{Uji t (Parsial)}

Dari hasil uji t dapat dilihat bahwa nilai Signifikan (Sig) untuk Book Tax Gap (BTG) adalah 0.003 yakni lebih kecil dari 0.05, sihingga dapat disimpulkan bahwa Book Tax Gap berpengaruh signifikan terhadap penghindaran pajak. Sementara nilai signifikan (Sig) Kepemilikan Asing (KA) nilainya 0.988 atau lebih besar dari 0.005 sehingga dapat disimpulkan bahwa Kepemilikan Asing tidak berpengaruh signifikan terhadap penghindaran pajak.

Tabel 1. Hasil Koefisien dan Signifikansi Uji t

\begin{tabular}{|c|c|c|c|c|c|c|}
\hline \multicolumn{7}{|c|}{ Coefficientsa } \\
\hline & & \multirow{2}{*}{\multicolumn{2}{|c|}{ Unstandardized Coefficients }} & \multirow{3}{*}{$\begin{array}{c}\text { Standardized } \\
\text { Coefficients } \\
\text { Beta }\end{array}$} & \multirow[b]{3}{*}{$\mathrm{t}$} & \multirow[b]{3}{*}{ Sig. } \\
\hline & & & & & & \\
\hline \multicolumn{2}{|l|}{ Model } & $\mathrm{B}$ & Std. Error & & & \\
\hline \multirow[t]{3}{*}{1} & (Constant) &, 179 &, 029 & & 6,191 &, 000 \\
\hline & BTG &, 369 &, 110 &, 615 & 3,369 &, 003 \\
\hline & KA &, 000 &, 032 &,- 003 &,- 015 & ,988 \\
\hline
\end{tabular}

a. Dependent Variable: TA

\section{Uji F (Simultan)}

Uji F (simultan) yang dilakukan dengan uji Anova menunjukkan bahwa nilai signifikan (sig) adalah 0.011 atau lebih kecil dari 0.05 sehingga dapat disimpulkan bahwa Book Tax Gap dan Kepemilikan Asing berpengaruh signifikan terhadap penghindaran pajak.

Tabel 2. Hasil Uji Anova

\begin{tabular}{|c|c|c|c|c|c|c|}
\hline \multicolumn{7}{|c|}{ ANOVAa } \\
\hline Model & & Sum of Squares & $\mathrm{df}$ & Mean Square & $\mathrm{F}$ & Sig. \\
\hline \multirow[t]{3}{*}{1} & Regression &, 065 & 2 &, 033 & 5,783 &, $011^{\mathrm{b}}$ \\
\hline & Residual & , 107 & 19 &, 006 & & \\
\hline & Total &, 173 & 21 & & & \\
\hline
\end{tabular}

a. Dependent Variable: TA

b. Predictors: (Constant), KA, BTG 


\section{Upaya Pemerintah Dalam Mengantisipasi Penghindaran Pajak}

Pemerintah sebenarnya sudah melakukan beberapa upaya untuk mengatasi permasalahan terkait penghindaran pajak di Indonesia, yaitu dengan adanya pasal-pasal yang bertujuan sebagai anti-tax avoidance dalam Undang-undang Nomor 36 Tahun 2008 Tentang Perubahan Keempat Atas Undang-undang Nomor 7 Tahun 1983 Tentang Pajak Penghasilan. Undang-undang ini selanjutnya di ikuti Berikut ini ulasan perkembangan regulasi terkait upaya penghindaran pajak berdasarkan modus yang digunakan

\section{Regulasi Praktik Transfer Pricing}

Sebagai upaya untuk menangkal praktek transfer pricing Dirjen Pajak telah mengeluarkan Surat Edaran Nomor SE - 04/ PJ.7 / 1993 tentang Petunjuk Penanganan Kasus-kasus Transfer Pricing. Dalam surat edaran tersebut disebutkan bahwa hubungan istimewa dapat berimplikasi pada kekurangwajaran harga, biaya atau imbalan lain yang direalisasikan dalam transaksi usaha

\section{Regulasi untuk menangkal Praktik Thin Capitalization}

Keputusan Menteri Keuangan Republik Indonesia nomor 1002/KMK.04/1984 tentang Penentuan Perbandingan Antara Hutang dan Modal Sendiri Untuk Keperluan Pengenaan Pajak Penghasilan. Dengan adanya regulasi ini maka perbandingan modal sendiri dan hutang adalah 3 : 1 hal ini untuk menghindari upaya penghindaran pajak melaui thin capitalization. Namun peraturan ini hanya berlaku sangat singkat karena pada tanggal 8 Maret 1985 regulasi ini ditunda penerapanya karena dianggap dapat menghambat perkembangan dunia usaha.

\section{Regulasi Untuk Mengantisipasi Praktik Treaty Shopping}

Dalam pasal 18 Undang-Undang Pajak Penghasilan telah diatur upaya untuk menghindari praktek treaty shopping. selanjutnya Dirjen pajak menerbitkan beberapa surat edaran seperti SE - 01 /PJ. 10/1994, tentang Surat Keterangan Domisili. Surat edaran tersebut mengatur mengenai kewajiban bagi wajib pajak untuk menunjukkan Surat Keterangan Domisili/SKD apabila menerapkan tarif pajak rendah atau bebas pajak atas pembayaran penghasilan keluar negeri sebagaimana diatur dalam tax treaty. 
Kemudian diterbitkannya Surat Edaran Direktur Jenderal Pajak Nomor: SE 04/PJ.34/2005, tentang Petunjuk Penetapan Kriteria "Beneficial Owner" Sebagaimana Tercantum Dalam Persetujuan Penghindaran Pajak Berganda Antara Indonesia dengan Negara Lainnya. Regulasi ini diterbitkan untuk menegaskan bahwa untuk bisa menikmati fasilitas penurunan tarif atas penghasilan berupa dividen, bunga dan royalti yang diatur dalam tax treaty antara negara Indonesia dengan negara treatypartner, selain kewajiban menunjukkan Surat Keterangan Domisili (SKD), wajib pajak juga harus merupakan beneficial owner dari penghasilan berupa dividen, bunga dan royalty tersebut.

Surat Edaran Direktur Jenderal Pajak Nomor: SE-03/P J.03/2008 tentang Penentuan Status Beneficial Owner, menggantikan Surat Edaran Direktur Jenderal Pajak Nomor SE-04/PJ.34/2005. Surat Edaran tersebut hanya menegaskan pengertian Beneficial Owner dan kewajiban untuk menunjukkan Surat Keterangan Domisili (SKD) apabila menerapkan "reduced rate" Tax Treaty atas pembayaran bunga, dividen dan royalti kepada penduduk (resident) Negara Mitra. Selain itu, Surat Edaran Nomor: SE03tersebut menghilangkan pernyataan bahwa "Special Purpose Vehicle- SPV" yang berbentuk Conduit Company, Passthrough Company dan Paperbox Company tidak termasuk BeneficialOwner. Ketiga perusahaan merupakan berbagai bentuk dari SPV.

Disamping kedua Surat Edaran Direktur Jenderal Pajak, upaya untuk menangkal praktik treaty shopping juga terlihat pada ketentuan limitation on benefit yang tercantum dalam tax treaty antara negara Indonesia dengan Amerika Serikat. Ketentuan tersebut memberikan batasan yang sangat rinci mengenai kriteria resident yang dapat menikmati fasilitas tax treaty antara kedua negara yang mengikat peijanjian tersebut.

\section{Regulasi Praktik Controlled Foreign Corporation (CFC)}

Ketentuan CFC telah diatur dalam Pasal 18 ayat (2) Undang-undang Pajak Penghasilan (PPh), kemudian pada tanggal 29 Desember 1994 telah diterbitkan Keputusan Menteri Keuangan Republik Indonesia nomor 650/KMK.04/1994 tentang Penetapan Saat Diperolehnya Dividen Atas Penyertaan Modal Pada Badan Usaha di Luar Negeri yang Sahamnya Tidak Diperdagangkan di Bursa Efek. Yang ditindaklanjuti dengan diterbitkannya Surat Edaran Direktur Jenderal Pajak Nomor: SE-22/PJ.4/1995. Kemudian pada tahun 2008 diterbitkan PMK Nomor 256/PMK.03/2008 dan Peraturan 
Direktur Jenderal Pajak (PER) Nomor 59/PJ/2010 tentang Penetapan Saat Diperolehnya Dividen oleh Wajib Pajak Dalam Negeri atas Penyertaan Modal pada Badan Usaha di Luar Negeri (BULN) selain Badan Usaha yang Menjual Sahamnya di Bursa Efek. Karena dianggap memiliki beberapa kelemahan kemudian Regulasi ini disempurnakan melalui Peraturan Menteri Keuangan (PMK) No.107/PMK.03/2017 tentang Penetapan Saat Diperolehnya Dividen oleh Wajib Pajak Dalam Negeri atas Penyertaan Modal pada Badan Usaha di Luar Negeri (BULN) selain Badan Usaha yang Menjual Sahamnya di Bursa Efek

\section{KESIMPULAN}

1. Kepemilikan asing tidak berpengaruh signifikan terhadap Tax Avoidance pada sektor perushaan makanan dan minuman yang terdaftar di BEI tahun 2017-2018.

2. Book tax gap berpengaruh signifikan terhadap Tax Avoidance pada sektor perusahaan makanan dan minuman yang terdaftar di BEI tahun 2017-2018.

3. Kepemilikan asing dan book tax gap berpengaruh signifikan terhadap Tax Avoidance pada sektor perushaan makanan dan minuman yang terdaftar di BEI tahun 2017-2018.

4. Pemerintah telah menerbitkan beberapa regulasi terkait Tax Avoidance ini melalui Undang-undang perpajakan, Keputusan Meteri Keuangan dan Surat Edaran Dirjen Pajak. Sebagian regulasi ini mengalami beberapa kali penyesuaian dengan tujuan penyempurnaan, namun ada juga regulasi yang baru setahun lalu dibatalkan penerapannya karena dianggap menghambat perkembangan dunia usaha. Regulasi yang ada saat ini masih perlu disempurnakan dan perlu dukungan kebijakan keterbukaan data perbankan dan kerjasama negara-negara ditingkat internasional untuk menutup peluang penghindaran pajak ini.

\section{REFERENSI}

Anggraini , 2011. Pengaruh kepemilikan Institusional dan Kepemilikan Asing terhadap Pengungkapan Pertanggungjawaban Sosial Perusahaan dalam Annual Report (Studi Empiris pada Perusahaan Non Keuangan yang tercatat di BEI Tahun 2008-2009)", Skripsi, Fakultas Ekonomi Universitas Diponegoro, Semarang. 
Cheng, C. S. A., Huang, H. H., Li, Y., \& Stanfield, J. (2012). The effect of hedge fundactivismon corporate tax avoidance.The Accounting Review87(5), 1493-1526.

Fadhilah, Rahmi. (2014). Pengaruh Corporate Governance terhadap Tax Avoidance. Jurnal Universitas Negeri Padang

Guire, Sean Mc., Dechun Wang dan Ryan Wilson. "Dual Class Ownership and Tax Avoidance".American Taxation Association Midyear Meeting: Jata Conference. 2011.

Hartati, W., Desmiyawati, \& Julita. (2015). Tax Minimization, Tunneling Incentive dan Mekanisme Bonus terhadap Keputusan Transfer Pricing Seluruh Perusahaan yang Listing di Bursa Efek Indonesia. Jurnal SNA.

Ibrahim , Salihu, Annuar, Obid, 2015 Foreign investors' interests and corporate tax avoidance: Evidence from an emerging economy Journal of Contemporary Accounting \& Economics, Department of Accounting, International Islamic University Malaysia.

Kiswanto, N., \& Purwaningsih, A. (2013). Pengaruh Pajak, Kepemilikan Asing, dan Ukuran Perusahaan terhadap Transfer Pricing pada Perusahaan Manufaktur di BEI Tahun 2010-2014, Jurnal UAJY.

Kurniasih, Tommy dan Maria M. Ratna Sari. 2013. Pengaruh Return On Assets, Leverage, Corporate Governance, Ukuran Perusahaan, dan Kompensasi Rugi Fiskal pada Tax Avoidance. Buletin Studi Ekonomi Vol 18, No.1, Halaman 58-65

Masri, Indah dan Martani, Dwi. 2012. Pengaruh Tax Avoidance Terhadap Cost Of Debt. Jurnal Program Pasca Sarjana Ilmu Akuntansi. Fakultas Ekonomi Universitas Indonesia.

Resmi, S. 2014. Perpajakan Teori dan Kasus Buku 1 Edisi 8. Jakarta: Salemba Empat.

Sugiyono. 2013. Metode Penelitian Kuantitatif, Kualitatif, dan Kombinasi (Mixed Methods). Alfabeta. Bandung.

Suryana, Anandita Budi. (2013). “Menisik Pajak Perusahaan Global”.2013. http://www.pajak.go.id/content/article/menisik-pajak-perusahaan-global.

Undang-Undang Republik Indonesia Nomor 36 Tahun 2008 tentang Pajak Penghasilan 